\title{
The Nature of the Modern Crisis in U.S.-Russia Relations
}

\author{
How to Break the U.S.-Russia Stalemate
}

Andrei A. Sushentsov, Maxim A. Suchkov

\begin{abstract}
The current state of U.S.-Russia relations is often compared with that of the Cold War. However, contradictions today between Moscow and Washington do not determine the dynamics of modern international relations. The confrontation between these two countries embraces all spheres (informational, economic, and political), resulting in a highly-dependent situation where conflict impacts all areas of cooperation. Relations between Russia and the United States clearly manifest a psychological phenomenon known as fundamental attribution error that indicates a tendency towards explaining the behavior and actions of other people by their bad qualities and one's own behavior by external circumstances. At the same time, the U.S-Russia confrontation is taking place against the background of a de facto political "civil war" within the American establishment, which has greatly disrupted foreign policy decision-making in Washington. "Russian meddling" has transformed from a threat to national security into a politicized driver of the internal political agenda. In reality, "Rus-
\end{abstract}

Andrei A. Sushentsov

Director, Institute for International Studies, MGIMO University.

ORCID 0000-0003-2076-7332

Room 3036, Vernadsky Prospect, 76, Moscow 119454, Russia

Maxim A. Sushkov

Senior Research Fellow, Laboratory of International Trends Analysis, MGIMO University.

ORCID 0000-0003-3551-7256,

Room 3036, Vernadsky Prospect, 76, Moscow 119454, Russia

This article was prepared with the support of grant RNF 17-78-20170.

DOI: $10.31278 / 1810-6374-2018-16-4-122-140$ 
sian meddling" is a myth as the Russian lobby is practically nonexistent in the U.S. In the short term, the dynamics of relations between Russia and the United States will remain negative. A possible strategy to minimize the consequences of the contradictions might be a search for constructive interaction in sensitive security issues.

Keywords: Russian-American relations, lobbying, information campaign, sanctions, communication

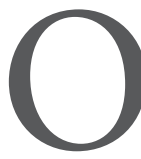

ver the past four years there has been plenty of discussion about the nature and character of the degradation taking place in Russian-U.S. relations. Many analysts compare the current situation with the Cold War, when the world was divided into two opposing camps seeking to expand their influence at each other's expense. The two superpowers were irreconcilable, balanced on the verge of war, and had complete control of the information space in their respective spheres of interest. Those were ideal conditions for confrontation.

The present situation is much more complex. Indeed, a large part of the international agenda is still affected by U.S.-Russian relations. The standoff between the two countries also increases tension in the international system, while the absence of any visible solutions to the current crisis adds to the feeling of "general confusion." But relations between Moscow and Washington no longer determine the dynamics of modern international relations as much as they did during the Cold War. The common space of confrontation-informational, economic, political — creates a high degree of interdependence when antagonisms are superimposed on the areas of cooperation. It is no longer a duel between superpowers. Many more key players are now involved in international processes (Lukin, 2016; Nikitin, 2016). Allies and opponents are becoming increasingly situational, and competition in such strategic industries as energy, communications, transport, arms trade, and information is emerging as a key international process. 
The current confrontation can hardly be rationalized. On the one hand, there is no complete understanding of the nature of the changes taking place: the Trump phenomenon, Brexit, conflicts in the Middle East, and the like. The opposing parties do not believe a big war is possible and allow themselves to walk on the edge. They understand the historical perspective-where exactly the world is going-differently.

Russia and the United States speak increasingly different languages and use different definitions of the same notions. In this situation not only diplomacy and political expertise often fail their missions, but even intelligence services prove helpless.

However, all this does not mean that the world has become as black-and-white as before or that there are only us and our conflict and nothing else. There are increasing signs of an emerging polycentric world. Bloc discipline is slackening not only between Russia and its allies, but also within the West. Many EU countries have expelled Russian diplomats, but it is much more important to look at which countries have not done so and why.

The current developments in Russian-U.S. relations are not a new Cold War (Safranchuk, 2018; Legvold, 2016). Yet the exchange of political and military signals is becoming increasingly harsh: provocations, sabotage, and compromising information campaigns have become more acrid, as evidenced by events in Aleppo and Idlib, alleged chemical attacks in Syria, the Skripal provocation, attempts to derail the Nord Stream-2 gas pipeline project, and the situation in Ukraine.

Leading Western governments are not the only ones involved in this confrontation. There are also minor countries that have the experience of staging provocations, as well as leading businessmen, most of whom avoid publicity, but whose interests suffer because of political processes.

In order to understand the motives for U.S. actions, one should take a closer look at the peculiarities of the political process in the United States and factors that mold political mentality in America.

\section{NEOCROPORATIVISM, "IRON TRIANGLES," AND "ISSUE NETWORKS"}

The political process in the U.S. is segmented and dominated by persistent patterns, voluntary associations, public debates on various 
issues, wide "dispersion" of power involving an unlimited number of participants, minimal centralization of the decision-making process, and a limited possibility to adopt final decisions.

The three key forms of this system are "iron triangles," "issue networks," and neocorporativism (Jordan, 1981; Heclo, 1978).

Neocorporativism, as a system of dialogue between members of the government and groups representing the interests of economic sectors or social groups (Schmitter, 1997), is perhaps the clearest and the most familiar channel for the Russian side in building relations with its American partners. However, the success of such contacts varies widely. While business councils and joint business projects until recently showed at least minimal activity in advancing a positive bilateral agenda, attempts to establish relationships with the influential National Rifle Association of America ended tragically. Gripped by mutual suspicion, the FBI reacted quite nervously to such "an approach" by Russian citizen Maria Butina.

Things are even worse at the level of "issue networks" and "iron triangles."

"Iron triangles" are stable political relationships comprising government agencies, congressional committees, and interested groups (lobbyists) (Freeman, 1964). Such relationships are based on corporate solidarity, with key public resources in specific areas distributed between the "insiders" and access denied to "outsiders." It is extremely difficult to find a way into such relationships, as access to these triangles is complicated even for the U.S. president. These relationships generate perhaps the biggest political returns, but Moscow has not started to deal with them professionally yet.

In opposition to "triangles" as networks with a stable composition of participants, there are more amorphous political associations known as "issue networks" (Heclo, 1978). They are characterized by greater flexibility in selecting their members, fragmented decisionmaking, and the absence of an authoritative policy-making center. Such networks often comprise government officials and Congressmen, party activists, representatives of different interest groups, and experts from academic organizations or think tanks, who may not only share 
financial interests, but who may also want to make public policy more effective in a particular area (Degtyarev, 2003). This complicates interaction with the United States, but some American researchers believe that the fragmentation of American policy may be good as it does not allow the centralized system of government to adequately solve problems everywhere at once (Jordan, 1981). This system "invites" foreign governments and lobbyists to "present" their interests on the American market of political services, provided their "commodity" is properly "marked" and clear to the American "consumers." Russia has problems with this too.

In addition, the decision-making system within the American government bureaucracy has at least three levels (Allison and Zelikow, 1999). At the first one, the final decision is made by the top segment of the hierarchy, and the decision per se is a crystallized and unified expression of state interest. At the second level a decision is the result of competitive interaction between different agencies within the bureaucratic system. This is where the notorious inter-agency competition manifests itself most graphically.

Finally, at the third level, specific persons interact within the bureaucratic system through personal relationships, negotiations, and agreements. This is where atomized interests of concrete government officials clash within the bureaucratic system involved in the decisionmaking process. This is where points of entry are to the American system with one's own agenda. It also offers potential opportunities, including those for close interaction with the Congress, which Russia has not considered in real earnest yet.

\section{ATTRIBUTION ERROR IN BILATERAL RELATIONS}

At the current stage of Russia-U.S. relations there is a clearly manifested psychological phenomenon of fundamental attribution error, indicating a tendency to explain the behavior and actions of other people by their bad qualities and one's own behavior by external circumstances.

Russia believes that the purpose of U.S. policy is to cause damage to Russia. This is exactly what leading American strategists have been 
writing about for years. And this is exactly how Russia views the American pressure coming from all sides: NATO enlargement, color revolutions, deployment of military infrastructure near the Russian borders, and information campaigns (Trenin, 2013). Russia also regards the series of anti-Russian sanctions as a far-fetched pretext and a continuation of the policy to contain Russia. The conclusion drawn from these actions is quite clear: We have been challenged and we will not give in. The closest metaphor Russians can think of to describe the U.S. policy is the popular Netflix series "House of Cards," where cunning and corrupt politicians spin a web of intrigue in order to gain the upper hand.

Americans, in turn, believe that there is no one more cunning than Moscow. Democrats, the political mainstream, and mass media are convinced than Russia has carried out a successful operation to infiltrate its agent into the White House and is now rubbing its hands in sinister anticipation, while roguishly keeping silent. There are those who believe that even if Trump is not a Russian agent, he wreaks havoc and this is a direct result of Russian policy. Moreover, it would not be an exaggeration to say that there is a consensus on "Russian meddling" and a possible recurrence during the next elections. U.S. politicians strongly reject interference in their internal affairs as absolutely unacceptable and respond, albeit somewhat hectically, with sanctions.

Most Republicans are less preoccupied with Russia and believe that the main reason is Trump and his peculiar character. But even if Russia has nothing to do with the situation in America, there is no reason to show empathy for it. Yes, the U.S. will need Russia in the future to contain China-even though no one really knows how to make Russia do that-but at this very moment there is no reason why the Senate should vote against anti-Russian sanctions.

A handful of Russian and American experts who maintain contacts with each other and the political elites in both countries see how imperfect the picture really is (Stent, 2014; Graham and Rojansky, 2018). There are three obvious reasons explaining the difference in how Russian and American elites see the situation. 
First - different socialization and formative experiences; they are so different that the elites can hardly understand each other.

Second - different political cultures as a product of historical experience and national mentality. The Russian people attach more value to stability and predictability and seek to manage a conflict by relying on pragmatism. By contrast, Americans favor competition and open expression of disagreements, prefer a decentralized political system, and believe that ideology is good for politics. This difference in basic principles prevents Russian and American elites from getting on the same wavelength. Americans often view Russian pragmatism as cynicism, while Russians see hypocrisy in the Americans' value-based approach.

Finally, third - Russian and American elites have communicated with each other only sporadically or have no such experience at all. At best, they build up the image of the counterpart on the basis of the short conversations they have had with each other on the sidelines of official events. This is even truer of government staffers and civil servants on both sides whose understanding of each other is based more often than necessary on popular culture productions, politicized surveys, biased media reports or glib-tongued authors like Dugin or Brzezinski. A combination of these factors subsequently results in a clichéd perception of the opponent's motives and a paranoid analysis of his actions.

The problem is that there are seeds of a deeper crisis in the current Russian-American stalemate. The two countries' perception of each other is deeply asymmetrical. Russia underestimates the fact that the U.S. is still in a state of shock from alleged Russian interference in the elections. Even many of those who admit that the issue has been overly politicized in the U.S. believe that this is an act of war. Figurative wording the Russian leadership has been using with regard to this issue, such as "Let's talk this over and stop interfering in each other's affairs," only increases suspicions that Russia is planning something even more menacing for the next elections.

Americans, for their part, fail to see the strategic consequences of their sanctions. The initiatives churned out by the American 
establishment, hurt by the purported interference and eager to punish the Kremlin, reduce Russia's maneuvering room in relations with the West and solidify Moscow's opinion of the United States as a strategic opponent. Russia views the sanctions as a continuation of the classical American policy to contain and crush the country. This further prods Russia into building a deeper relationship with China.

\section{AN UNREACHABLE HORIZON}

The U.S.-Russia confrontation is unfolding amidst a political "civil war" in Washington, and this is a major difference from the previous standoff. There are no illusions that strategic disagreements between the two countries remain irreconcilable, even beyond the current political crisis. However as long as Russia is used as an element of internal political debate in the United States centering around President Trump and his actions, there is no way to normalize bilateral relations. Trump's healthy instincts are sabotaged by the American establishment-some members of the presidential administration and Congress, and midlevel bureaucrats (Bezrukov and Sushentsov, 2016). This has led to a massive disorganization of the foreign policy process in Washington and the loss of a single entity hitherto represented by the United States. Furthermore, some members of the presidential administration are obviously suffering from bouts of youthful maximalism as evidenced by U.S. Secretary of the Interior Ryan Zinke's remarks suggesting that the Russian fleet should be locked up in the Black Sea. At the same time, Americans do not want to get involved in a drawn-out, let alone direct, military conflict.

Russian and U.S. leaders meet rarely and when they do, an analogy from the Cold War era is immediately found. The latest summit in Helsinki was not an exception. Some compared it with the meeting between Nikita Khrushchev and Dwight Eisenhower during the Soviet leader's first visit to the U.S. in September 1959. But even more observers alluded to the Gorbachev-Reagan talks in Reykjavik in 1986. No agreements were signed then, but the respectful relationship established by the two leaders and the follow-up work on concrete issues made it possible for the two countries to seal the Intermediate-Range 
Nuclear Forces Treaty (INF Treaty) a year later. At home Gorbachev was severely criticized by the military, party members, and public activists for "surrendering" to Washington. They blasted the summit as the Soviet Union's failure. Gorbachev responded to this criticism by saying that "Reykjavik is not a failure but a breakthrough... We have looked beyond the horizon."

Three decades later everything looks completely different. Although historical parallels are quite relative, now it is the American establishment and the general public that appear to be hurt by the results of such meetings. Now it is America that does not want such meetings to bring victory for international security even though, just like thirty years ago, the leaders of the two nuclear powers keep talking about the need to negotiate. Now it is the Americans who fail to look beyond the horizon as if they have grown shorter. Washington seems to care about the rest of the world even less than before, while the entire agenda of relations with Russia has been reduced to the issue of "breaking into" one of the U.S. parties' servers.

Now it is the U.S. president who has been accused of "betraying" his country. Trump was still on his way home from Finland when some people in the U.S. started attacking him for treason, others blasted him for glaring incompetence (claiming that this summit was even worse than the meeting with North Korean leader Kim Jong-un), while still others left their social networks in order to overcome the shock from what they believe was "a defeat of America." The opposition mass media-basically all key media outlets in America are opposed to the president-have been citing sources in the presidential administration as saying that Trump could not separate the issue of "interference" from the issue of "collusion," and that by accepting the former he would automatically admit the latter.

In real life, however, Trump has been trying hard to separate one from the other. While not denying interference, he has been emphasizing the fact that it happened during Obama's tenure, and if anyone is to be blamed for connivance and omission, it is his predecessor. Trump also keeps insisting that there was no "collusion" and he won the election fair and square due to his brilliant campaign. Absolutely sure of 
his victory, with no concrete evidence exposing the role of Moscow and personally President Putin, and wishing to address more specific issues, the U.S. leader wants to close this chapter. However the eccentric president's arguments fall on deaf ears and reach only his voters. Gripped by the fear of any contact with Russian officials, members of all segments of the American government act with caution bordering on absurdity. But what is particularly counterproductive for bilateral relations is that the U.S. president himself is under close observation: Any word he utters, any action he takes, and any non-verbal signal he sends are scrutinized through the lens of his purported ties with Russia and personally with Putin, without a doubt harmful for America.

The issue of "Russian meddling" has long transformed from a threat to national security, as any foreign interference undoubtedly is, into a politicized driver of the internal political agenda used by one group of political forces against another group. Any proposal from Russia becomes a new irritant for Trump's opponents, and the "firewall" which separates the two opposing camps flares up with a new blaze of information campaigns.

It must be said for the sake of justice, though, that Trump's behaviorfrom his statements to the notorious language of gestures-only adds fuel to the fire and gives new food for thought to those seeking it for months ahead (Suslov, 2016). In this respect, Trump is an "aggravating factor" for attempts to normalize relations between the two countries.

Under other circumstances, when negotiations between the two competing powers turn into a contest of the will and ingenuity of their leaders and the efforts of their teams, Russia could get credit for its work and hope for success, but this is not the case. Trump's opponents will seek to disavow even the smallest progress made, and the president himself is hardly able to implement any agreement with Moscow, even despite his readiness to sacrifice political capital for the sake of peace. So it is unlikely that the two countries will be able to look beyond the horizon any time soon. Now that the risks associated with the degradation of confrontation to a direct conflict are becoming increasingly less manageable, decision-makers in both countries have to and will look for various versions of "competition by the rules." 


\section{TO BE OR TO SEEM?}

Good solutions are in short supply when confrontation becomes overgrown with various elements and is increasingly irrational. Naturally, we can wait for the crisis over Trump to subside, but there are no grounds for assuming that relations between Moscow and Washington will start improving when the incumbent American president leaves office. Thus, expectations of what can be done should be moderated.

Firstly, while "waiting for something better," it would be quite productive to invest in each other's education in order to get to know the counterpart better. Multi-billion budgets, strategic plans, and military preparations must not be built on such a shaky basis as psychological complexes and fears. Expert assessment should be measured, among other things, by the number of hours spent face-to-face with people whose accurate evaluation becomes so critical. For the time being, such expert assessment is almost nonexistent in the political circles of both countries.

Secondly, contacts with Congress are of paramount importance as only they can provide a chance for progress in stopping the tide of sanctions. However, Russian contacts in the U.S. Congress have always been relatively weak and attempts to strengthen them, as a rule, go no further than the admission that parliamentary diplomacy does not work. At the same time, even rare contacts with U.S. congressmen reveal serious gaps in the Russian legislators' understanding of their overseas counterparts' role in the American decision-making system.

A group of American legislators visited Moscow ahead of the Putin-Trump meeting in Helsinki. They were received at the Foreign Ministry, the State Duma, and the Federation Council. The group included senators from far-flung states who do not deal with foreign policy, with not a single Democrat among them. Duma deputies erroneously took them as "allies" and greeted them with applause. However back home Senator John Kennedy compared the Russian government with mobsters who only value power, status, and money and lack "political philosophy."

This episode showed, first of all, that the congressmen had no obligation to the White House and did not intend to engage in sweet talk 
before the summit. They were not the doves sent by the administration to deliver good news; on the contrary, they were the hawks the White House tried to convince that there would be no covert dealing with Moscow behind the Congress' back. In Washington, Donald Trump is suspected of collusion with the Russians. So the congressmen came to Moscow not with peace, but with inspection.

Secondly, Senator Kennedy's remark about "political philosophy" is not just an empty phrase; American ideology is indeed one of the key motives behind U.S. actions, a sort of "friend or foe" marker. American allies have to imitate and learn the U.S. political language in order to sound familiar. Those who do not do so are stigmatized in the U.S. as cynics who cannot be trusted.

Russia is in a somewhat different weight category than American allies and does not have to imitate anything. However, in order to improve relations with America it has to replace its complaints about Russophobia with firm arguments showing why our pragmatism is better than their "value-based approach." Russia's pragmatism in the Middle East is a vivid example of such an effective policy.

Thirdly, the lack of trust between the sides does not necessarily block their interaction. But in order to continue such interaction, both sides should constantly assure each other that they do not have hostile intentions. The format of such signals can be discussed. With time this practice can develop into a culture of Russian-American disagreements which characterize mature relations between competitors.

Russia should seek to take part in the U.S. foreign policy discussion in order to bring common sense into debates concerning Russia.

The constant flow of American media reports creates the impression of colossal and all-round influence exerted by Russia. The tandem of Russian trolls and hackers has become a real nightmare for the U.S., generating a deep-seated paranoia in high offices. This picture may fuel Moscow's ego and entertain the public, but in reality Russian influence in the United States is a myth. Moreover, the Russian lobby is practically nonexistent, as proved by the spasmodic attempts of Russian businessmen to knock on all doors in Washington out of fear of falling under sanctions. 
Trying to influence U.S. policy today would be hardly practical and may even cause bilateral relations to take yet a steeper dive. However, constant participation in the U.S. foreign policy discussion in order to create an atmosphere of common sense when debating issues related to Russia should become a long-term foreign policy goal for Moscow. No such task has been set so far, while numerous Russian organizations engaged in expert and humanitarian contacts often miss the target.

As a result, no reputable voice from Russia, respected, accepted, and professional, is present in the American foreign policy discussion. Publications by Dmitry Trenin (Trenin, 2017), Fyodor Lukyanov (Lukyanov, 2018), Andrei Kortunov, and many others are a rare example of constant efforts to this end. Occasionally, progress is made at the top level like in Vladimir Putin's article published in the New York Times in 2013 under the title "A Plea for Caution from Russia," where he warned against attacks on Syria. But this does not change the overall picture: Russian authors are a rarity among media reports read by Washington. Russian speakers have appeared in the U.S. Congress only a few times and most of them criticized their own government.

One may argue, of course, that no one in the U.S. wants to receive and hear us out and never will. In reality, Americans ignore weak arguments and downright propaganda. There is a long-standing tradition in the U.S. to mistrust its own government. Sound arguments always find their audience and those in doubt always ask questions. So, Russia must play on this field. Even if it cannot convince the incumbent administration, it can sow doubt among experts and in society, thus making it harder for an inconvenient decision to be adopted.

Without a doubt, there is demand in the U.S. for a second opinion from Russian pundits, but it must be a calm and constructive voice, which will stay away from reproaching and will instead appeal to empathy and common sense to explain the motives for Russia's actions. However, only a few Russian experts are able to speak knowledgeably in front of a critically-minded audience and show an understanding of the American mentality.

In order to work systemically on this track, Russia needs to create its own lobby in the United States. But doing this would be, above all, 
an intellectual challenge. It is hard for Russian elites to understand that American politics is competitive, its outcome is not predetermined, there is a real foreign policy discussion, and polemics in society, the media, and Congress are not an orchestrated show (Suchkov, 2013). Many will also be surprised to find out that even the American government has to exert maximum effort in order to win over the press. In fact, the George W. Bush administration mobilized members of its Cabinet in order to convince the public and Congress of the need to start an operation in Iraq. But the Trump presidency is one big media campaign.

It is believed that creating a lobby would be an encroachment upon American sovereignty: if we do not want the Americans to lobby in the Russian parliament, we should do likewise. Perhaps the reason for this attitude is that the Russian elites, unlike their European, Turkish, Israeli, or Chinese counterparts, did not study in the U.S. and lack well-established connections, contacts, and access to the American establishment. But the American political practice looks at this differently. The operation of the Iranian lobbies is an example of successful work in an unfriendly environment. Studying this experience would be quite valuable for Russia.

In other words, a Russian analytical center or a research institute should open a branch in Washington in order to participate in the American foreign policy discussion all the time. Its employees should write articles for leading American mass media, prepare analytical reports, organize presentations at universities and think tanks, attend various functions in Washington, mingle with members of political and decision-making circles, consult the editorial boards of major media outlets, and reply to informal inquiries from the Congress staff and executive bodies. It is important that the presence of such a center be legalized according to American laws and contacts with Russian analysts be not viewed as compromising.

Organizing such a center would not be very costly but can significantly reduce losses from sanctions. Americans have gone on a witchhunt because they are afraid of clandestine Russian influence as unscrupulous and pursuing selfish goals. In this situation Russia should 
drop the veil of secrecy and make its presence and influence explicit. A respectable and calm Russia, along with a sarcastic, accusatory, and irreconcilable Russia, can improve the perception of our country in the United States and the world in general. Even our allies often rely on the image of Russia created by the American mainstream media. It is time Russia created its own image itself.

Thirdly, reliance on firm legalism does not work today. Differences in the understanding of the UN Charter and UN Security Council decisions, so traditional for Russian-American relations, have assumed grotesque forms. There is actually a war of wording, built into the information confrontation between the two countries. In this situation, both countries need, firstly, to drop antagonizing tactics as the main principle of their policy as they are predictable, limit the room for maneuver, and worked better when bloc discipline was tighter and borders in the world were clearer. Second, reliance on common sense and empathy rather than legalism is more likely to make its way into the hearts of both the elites and the general public. Third, it is necessary to be flexible and act preemptively as any delay in response amidst swift and rapid flows of information will only lead to a defeat.

It is very hard to compete on the general information field, and there is a big temptation to seize full control of information flows again. But Moscow has repeatedly shown its ability to improvise as it did with its prompt response to the Polish president's plane crash or its initiatives concerning chemical disarmament in Syria and deployment of peacekeepers in Donbass, which produced the desired public effect in what seemed to be a hopeless situation.

Correct communication can strip our opponents of emotionally charged arguments. Naturally, complications in bilateral relations do not boil down to just communication problems. But more energetic efforts on this track can bring concrete political dividends. Russia should broaden the array of metaphors it uses to describe international processes. So far only two have been used most often: the metaphor of a Cold War-era duel and the metaphor of the allied bloc that defeated Nazism. This is the main reason why Russia's latest international initiatives smell of historicism: the idea of building a global anti-terrorist 
coalition, the desire to act in Syria together with the United States and France as allies, or the search for a big deal with the U.S. on European security and the Ukraine crisis.

However, it seems that international relations no longer work like this. It is quite obvious that modern politics, both domestic and international, is inseparable from popular culture, religion, and mass media. Although our society is secular, the fabric of public discussion is filled with biblical metaphors, and key political processes can be described with one of them: for example, the conversion of Saul to Paul, David's victory over Goliath, the return of the Prodigal Son, or the parable of the Pharisee and the Publican. Biblical metaphors also provide a breeding ground for civic myths: for example, the Star Wars saga with its own notion of the balance of power and the conversion of good characters into bad ones and vice versa. In the case of Russia, its current image as an offending country on the wrong side of history can be transformed with the help of correct communication into the image of a country which, like the Publican, is more righteous than the Pharisee who keeps talking about his sanctity.

Confrontation has become a norm in relations between Russia and the United States. This new state may last into the foreseeable future. But even in this case there is no reason to let American mass media mold the image of Russia.

\section{HOW TO GET RELATIONS OUT OF THE IMPASSE?}

In the short term the dynamics of Russia-U.S. relations will remain negative. Breakthroughs or signals indicating that these relations are steadily going back to relatively normal are unlikely. To a certain extent all of us will be hostages of the political situation in the United States, which is likely to remain complex and occasionally ricochet at Russian-U.S. relations.

Mutual recriminations traded by Moscow and Washington make the situation not just complex, but very confusing. There is a lot that is superficial, far-fetched, and unreliable. Many think that such illusiveness is its main underlying feature and also a new constant in RussiaU.S. relations. 
But alongside this uncertainty and confusion, a number of objective tendencies have evolved that make Russian-American relations complex and lie at the core of what can be called inextricable contradictions. This concerns first and foremost the rearmament program, now well underway in the U.S., which focuses on the modernization of strategic nuclear forces. Under a negative scenario this may lead to a new round of "militarization of international relations" and a new arms race between Russia, the United States, and probably China at a time when the strategic arms limitation regime is crumbling. This may also trigger rearmament and arms modernization campaigns in other influential countries wishing to have the most advanced weapons.

On top of it all, the two countries are divided by deep contradictions over the crises in Ukraine and Syria, the security architecture in Europe and the Middle East, and the unilateral use of force by the United States.

It is impossible to count on success in building relations with Washington without taking into account the peculiarities of the American foreign policy process outside top-level contacts between presidents.

Russian and U.S. leaders are ready to engage in constructive dialogue in order to rescue bilateral relations from the current crisis. But one should not expect the next top-level meeting to be followed by a new reset. Despite the two leaders' determination to look for solutions, the U.S. president's initiatives on the Russian track can easily be rolled back and will have no long-term constructive effect on bilateral relations. The notorious "RESET" is out of the question in the current circumstances. However, the system freeze-both in Russia-U.S. relations and inside the United States between Trump and his opponents-is obvious and, continuing the computer analogy, fixing it will require the two sides to press "CTRL+ALT+DEL" from time to time in hopes of restarting the system. Thus, further contacts will be needed.

A three-pronged approach where (1) the sides seek to establish more or less constructive interaction on pressing security issues, with (2) the two leaders sincerely showing good will in their relationship, and (3) the risk of conflict remaining low, would probably be the best possible line of action in a whirlpool of political absurdities. 


\section{References}

Allison, G. and Zelikow, P., 1999. Essence of decision: explaining the Cuban missile crisis. 2nd ed. Reading, MA: Longman.

Bezrukov, A.O. and Sushentsov A.A., 2018. Fenomen D. Trampa i scenarii razvitiya rossijsko-amerikanskih otnoshenij [The phenomenon of D. Trump and scenarios for the development of U.S.-Russian relations]. Sravnitel'naya politika, Vol. 9. 1, pp. 109-123.

Charap, S., 2013. Beyond the Russian reset. The National Interest, 126, pp. 39-48.

Degtyarev, A.A., 2003. Metodologicheskiye podkhody I kontseptual'nyie modeli v interpretatsii politiceskikh resheniy [Methodological approaches and conceptual models in interpretation of political decisions]. Politicheskiye issledovaniya, No. 2. pp.164-173.

Deibel, T., 2007. Foreign affairs strategy: logic for American statecraft. New-York: Cambridge University Press.

Graham, T. and Rojansky, M., 2016. America's Russia policy has failed. Foreign Policy, [online]. Available at: https://foreignpolicy.com/2016/10/13/americasrussia-policy-has-failed-clinton-trump-putin-ukraine-syria-how-to-fix/ [Accessed 31 October 2018].

Heclo, H., 1978. Issue networks and executive establishment. The new American political system. Ed. by Anthony King. Washington, D.C.: American Enterprise Institute, pp. 87-107, 115-124.

Jordan, G.A., 1981. Iron triangles, woolly corporatism and elastic nets: images of the policy process. Journal of Public Policy, 1(1), pp. 95-123.

Kortunov, A.V. and Frolov, A.V., 2015. Politika SShA v menyayushchemsya mire [U.S. policy in the changing world]. Mezhdunarodnaya zhizn', 11, pp. 1-26.

Legvold ,R., 2016. Return to Cold War. Cambridge: Polity.

Lukyanov,F.A.,2018.Trump'sdefensestrategyisperfectforRussia. The Washington Post, [online]. Available at: https://www.washingtonpost.com/news/theworldpost/wp/2018/01/23/national-defense-strategy/?noredirect=on\&utm_term =. c8ddb6b79535 [Accessed 31 October 2018].

Lukin, A.I., 2016. Postbipolyarny mir: mirnoe sosushchestvovanie ili khaos? [Postbipolar world: peaceful coexistence or chaos?]. Mirovaya ehkonomika $i$ mezhdunarodnye otnosheniya, Vol. 60, 1, pp. 17-29. 
Nikitin, A.I., 2016. Novaya sistema otnoshenij velikih derzhav XXI veka: "kontsert" ili konfrontaciya? [New system of relations between great powers for the 21st century: "Concert" or confrontation?]. Polis. Politicheskie issledovaniya, 1, pp. 44-59.

Putnam, R., 1988. Diplomacy and domestic politics: the logic of two-level games. International Organization, 42(3), (Summer), pp. 427-460.

Safranchuk, I.A., 2018. Nekonstruktivnaya dvojstvennost' [Nonconstructive duality]. Russia in Global Affairs, Vol. 16, 4, pp. 210-219.

Schmitter, F., 1997. Neokorporativizm [Neocorportivism]. Polis, No. 2, pp. 14-22.

Sten,t A., 2014. The Limits of partnership: U.S.-Russian relations in the twentyfirst century. Princeton: Princeton University Press.

Suslov, D.V., 2016. Gudbaj, prezhnyaya Amerika? [Goodbye, former America?]. Russia in Global Affairs, Vol. 14, 5, pp. 13-21.

Suchkov, M.A., 2013. Vliyanie lobbi-grupp na formirovanie vneshnej politiki SSHA na Yuzhnom Kavkaze [Lobbies in the making of American foreign policy in the South Caucasus]. Vestnik MGIMO University, 3, pp. 18-24.

Trenin, D.V., 2013. Chetvertyj vektor Vladimira Putina (Vneshnyaya politika Rossii - chto izmenilos'?) [Vladimir Putin's fourth vector (Russian foreign policy: What has changed?)]. Russia in Global Affairs, 1, pp. 71-82.]

Trenin, D., 2017. What's the U.S.' best chance with North Korea? Russia. The New York Times, [online]. Available at: https://www.nytimes.com/2017/09/18/ opinion/north-korea-nuclear-weapons-russia.html [Accessed 31 October 2018]. 